\title{
Swim-up tekniği ile hazırlanacak semen örneklerinde trombositten zengin plazma etkisinin değerlendirilmesi
}

\author{
Examination of platelet rich plasma effect in semen samples to be prepared \\ by swim-up technique
}

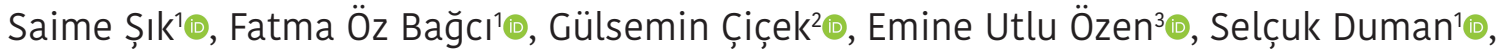 \\ Tahsin Murad Aktan'10
}

$\ddot{0 z}$

AMAC: Sperm motilitesi, erkek infertilitesinde önemli bir parametredir. İn vitro fertilizasyon tedavilerinde motil sperm elde etmek önem arz etmektedir. Bu nedenle farklı yüzdürme metotları birçok çalıșmanın konusu olup, en ideal yöntemin swim-up olduğu düşünülmüştür. Trombositten Zengin Plazma (TZP), içerdiği büyüme faktörleri nedeniyle ortopedi, plastik cerrahi, dermatoloji gibi farklı alanlarda kullanım bulmuştur. Çalışmamızda, Aktif-trombosit bakımından zengin plazma (A-TZP)'nın swim-up modelinde sperm motilitesine etkisini araştırmak ve yardımc üreme tedavilerine katkısının değerlendirilmesi amaçlanmıştır.

GEREC ve YÖNTEM: Çalıșmamıza semen için 30, kan bağıșı için 10 gönüllü katılmıştır. Alınan intravenöz kanlar TZP elde etmek için hazırland. A-TZP elde etmek için, trombositler $\mathrm{CaCL}_{2}$ ile aktive edildi, daha sonra TZP donduruldu ve deneysel kullanım gününe kadar $-20^{\circ} \mathrm{C}$ 'de saklandı. 30 gönüllünün rutin semen analizleri yapıldıktan sonra her örnek iki eşit hacimde ayrılmıştır. Ham (raw) olan kısım sadece takip edilmiștir ve çalıșma grubunun analiz dakikalarında motilite bulguları sadece bilgi vermek amacıyla sunulmuştur. Çalışma grubunda SP, A-TZP ile yıkama için seyreltildi ve santrifüj edildi, A-TZP'li katmana yüzmesi için 15,30 ve 45 dakika boyunca tabakalandı. Sperm hareketlilik analizi 15,30 ve 45 dakikada yapıldı.

BULGULAR: A-TZP'nin sperm motilitesini +3 ve +4 seviyesinde önemli oranda olumlu etkilediğini gözlemledik. Bu yükselişin en çok ve etkin olduğu dakikalar ise swim-up sonrası 15 . dakika civarıdır.

SONUCุ: TZP'nin sperm motilitesi üzerine anlamlı oranda etkisi bulunmaktadır. TZP, sperm motilitesi düşük intrauterin inseminasyon (IUI) ve intrasitoplamik sperm enjeksiyonu (ICSI) için sperm hazırlamada alternatif bir yıkama materyali olabilir.

Anahtar Kelimeler: Sperm, Swim-up, Trombositten Zengin Plazma (TZP)

${ }^{1}$ Necmettin Erbakan Üniversitesi, Meram Tıp Fakültesi, Histoloji ve Embriyoloji Anabilim Dalı, Konya, Türkiye

${ }^{2}$ SBÜ Kanuni Sultan Süleyman Eğitim ve Araştırma Hastanesi, Üremeye Yardıma Tedavi Merkezi, İstanbul, Türkiye

${ }^{3}$ Etlik Zübeyde Hanım Eğitim ve Araştırma Hastanesi , Üremeye Yardımcı Tedavi Merkezi, Ankara, Türkiye

\section{Yazısma Adresi/ Correspondence:}

Uzm. Dr. Gülsemin Çiçek

SBÜ Kanuni Sultan Süleyman Eğitim ve Araştırma Hastanesi, Üremeye Yardımcı

Tedavi Merkezi, İstanbul, Türkiye

Tel: $\quad$ +905544956315

E-mail: gulseminyuksel@gmail.com

Geliș/ Received: $\quad$ 15.11.2019

Kabul/ Accepted: 17.12 .2019

\section{ABSTRACT}

OBJECTIVE: The motility of sperm has importance for male infertility. It is important to yield high motile sperms during in vitro fertilizations. For this reason, different processing methods for sperms are subject for a lot of research. It is found that swim-up technique gives improved results for motility. Platelet Rich Plasma (PRP) contains a large spectrum of growth factors and is widely used in orthopedics, plastic surgery and dermatology treatments. The aim of this study was to investigate the effect of ActivePlatelet Rich Plasma (A-PRP) on sperm motility in swim-up model and to evaluate its contribution to assisted reproductive treatments.

MATERIAL and METHODS: In our study we collected thirty volunteers for seminal plasma usage and ten volunteers for blood donation. The collected intravenous blood was processed for PRP yielding. To obtain A-PRP, platelets were activated with $\mathrm{CaCL}_{2}$, then PRP was frozen and stored at $-20^{\circ} \mathrm{C}$ until the day of experimental use. After analysis of seminal plasma (SP) was done it was divided to two equal volumes. The unprocessed group was only used two compare sperm motility at the same time intervals. In the study group SP was diluted with A-PRP and for washing, centrifugation and A-PRP was layered for 15, 30 and 45 minutes to swim-up. Sperm motility analysis were done at 15 th, 30th and 45th minutes.

RESULTS: We observed that A-PRP had a significant positive effect on sperm motility at +3 and +4 levels. The highest increase in sperm motility is around 15th minutes after swim-up.

CONCLUSION: PRP has a significant enhancing effect on sperm motility. In patients with low sperm motility, PRP may be an alternative washing material at sperm preparation for intrauterine insemination (IUI) and intracytoplasmic sperm injection (ICSI).

Keywords: Sperm, Swim up, Platelet Rich Plasma (PRP)

\section{GíRiș VE AMAÇ}

İnfertilite, bireyi ve birçok zaman aileleri de doğrudan etkileyen sosyolojik yönleri de olan bir sağlık problemidir. Günümüzde infertil çiftlerin yaklaşık \% 40 'ında sorunun erkek faktörlü infertilite olduğu görülmüştür. Erkek faktörlü infertilitede sperm parametreleri önem arz eder ve en kritik parametrelerden biri de motilitedir. Spermiogram testi yalnızca infertilite tanısında değil, testisi etkileyen varikosel, inmemiş testis, kemoterapi veya radyoterapi gibi testiste sperm üretimini etkileyen durumlar için de önem arz eder. ${ }^{[1]}$ 
Yardımcı Üreme Teknikleri (YÜT) yardımı ile yapılan tedavilerde motil sperm elde etmek için farklı sperm hazırlama metodları halen kullanılmaktadır. Bu metodlar; basit yıkama, swim-up, dansite gradient gibi tekniklerdir. $\mathrm{Bu}$ metodlar arasında sperm hazırlamak için en ideal ve en çok kullanılan yöntemlerden biri ise swim-up tekniğidir. Swim-up tekniği, temiz medium katmanına yüzen modil sperm elde etme yöntemidir. ${ }^{[1]}$

Trombositten Zengin Plazma (TZP), tam kanın santrifüj edilmesi ile normale oranla daha konsantre trombosit elde edilmesini sağlamaktadır. Gerek TZP'nin kendisi gerekse TZP hazırladıktan sonra trombositlerin aktive edilmesi ise trombositlerden salınan büyüme faktörlerinin daha fazla oranda açığa çıkmasını sağlamaktadır. Aktive edilmiş trombositten zengin plazma (A-TZP); Transforming growth factor-beta (TGF- $\beta$ ), Fibroblast growth factor (FGF), Platelet derived growth factor (PDGF), Epidermal growth factor (EGF), Vascular endotelial growth factor (VEGF) ve sitokinleri konsantre halde içinde bulundurur. Bu büyüme faktörlerinin doku onarımı, hücre çoğalması ve anjiyojenezde rol oynaması nedeni ile ortopedi, plastik cerrahi, diş ve kadın doğum hastalıklarında farklı kullanım alanları bulmuştur. [2-4] Ürolojide; erektil disfonksiyon, üretral striktür, üriner inkontinans ve Peyroni hastalığında yapılmış çalışmalar mevcuttur. ${ }^{[5-8]}$ İyatrojenik vezikulovajinal fistüle sahip 12 hasta ile yapılan bir çalışmada 12 hastanın 11'inde belirgin iyileşme görülmüştür. ${ }^{[9]}$ Rekürren bakteriyel sistitli kadınlarda intravesikal PRP uygulaması ile kontrol grubu ile karşılaştırıldığında rekürrens oranının azaldığı ve yapılan uygulamanın herhangi bir olumsuz etkisinin olmadığı gözlenmiştir. ${ }^{[10]}$

Yaptığımız Pubmed ve diğer akademik taramalarda A-TZP'nin swim-up yöntemiyle sperm motilitesine olan etkisiyle ilgili herhangi bir çalışma bulunamamıştır (04/12/2019). Çalışmamızda, A-TZP'nin swim-up modelinde sperm motilitesine etkisini araştırmak ve yardımcı üreme tedavilerine katkısının değerlendirilmesi amaçlanmıştır.

\section{GEREÇ VE YÖNTEM}

Bu çalışmada 08.10.2018/30.11.2018 tarihleri arasında Necmettin Erbakan Üniversitesi Meram Tip Fakültesi Tüp Bebek Ünitesi'ne rutin semen analizi için müracaat eden, yaşları 18-50 arası toplam 30 adet gönüllünün semen örnekleri kullanıldı. İstenilen tahlil yönünden değerlendirilip sonuçları rapor edildikten sonra tıbbi atık olarak ayrılan semen örnekleri ile çalışıldı. TZP eldesi için gönüllü olarak kan veren 10 kişinin kan örnekleri ile çalışıldı. Çalışmaya katılan her gönüllümüzden bilgilendirilmiş gönüllü olur formu ile izinleri alındı.
Çalışmamız Necmettin Erbakan Üniversitesi Meram Tip Fakültesi İlaç ve Tibbi Cihaz Dışı Araştırmalar Etik Kurulu'nun 05.10.2018 tarih 2018/1510 no.lu izni ile gerçekleştirildi.

\section{Semen Örneklerinin Toplanması}

Semen örnekleri, 3-5 günlük cinsel perhizle Tüp Bebek Merkezi'ne gelen hastalardan, alınmış olup rutin spermiyogram testi yapıldıktan sonra çalışmaya dâhil edildi. Çalışmada azospermi dışındaki normospermi, oligospermi ve astenospermili semen örnekleri kullanıldı. Bu örneklerden elde edilen tüm motilite değerlerinin istatistiksel olarak analizi yapıldı ve bu veriler grafize edildi.

\section{Kan Örneklerinin Toplanması}

Çalışmamızda kan vererek gönüllü olmak isteyen 10 gönüllüden, içinde $2 \mathrm{cc}$ asit sitrat dekstroz-A (ACD-A)'lı enjektörlere $8 \mathrm{cc}$ kan alındı, aynı gün Trombositten Zengin Plazma eldesi için laboratuvarda çalşsıldı ve örnekler $-20^{\circ} \mathrm{C}$ 'de dondurularak saklandı.

\section{Trombositten Zengin Plazmanın Hazırlanması}

Necmettin Erbakan Üniversitesi Meram Tip Fakültesi Yardımcı Üreme Teknikleri Ünitesi Ar-Ge amaçlı laboratuvarında gönüllülerden elde edilen kan, 1:5 oranındaki asit sitrat dekstroz-A (ACD-A)'lı tüplere alınıp 1100 devirde 22 dakika soğutmalı santrifüj cihazında santrifüj edildi, santrifüj sonrası üstte kalan plazma alınıp 1:10 oranında \%10'luk $\mathrm{CaCl}_{2}$ ile karıştırıldı. $\mathrm{CaCl}_{2}$ ilavesi $550 \mu$ l plazmaya $27,5 \mu \mathrm{CaCl}_{2}$ olacak şekilde yapıldı. Pıhtı/fibrin yapısı oluşana kadar oda 1 sısında veya $37^{\circ} \mathrm{C}$ 'lik inkübatörde inkübe edildi. $\mathrm{Bu}$ işlem sonrasında elde edilmiş plazma tekrar 2700 devirde $15 \mathrm{dk}$ santrifüj edilip santrifüj sonrası süpernatant kısmı 1,5 mL'lik eppendorf tüplere konup $-20^{\circ} \mathrm{C}$ 'de saklandı. Çalışma günü daha önce elde edilip $-20^{\circ} \mathrm{C}$ 'de dondurulmuş halde bulunan TZP, oda isısında çözdürülüp kullanıldı.

\section{Semen Örneklerinin Swim-up Tekniği ile Yüzdürülmesi}

Çalışmada likefiye olmuş semen numuneleri eşit hacimlerde ikiye ayrıldı, Ham (raw) olan kısım sadece takip edildi ve çalışma grubunun analiz dakikalarında motilite bulguları sadece bilgi vermek amaciyla sunuldu. Kalan kısım ise çalışma grubu olarak A-TZP ile muamele edilecek kısım olarak değerlendirildi. Çalışmamızda bir kontrol grubu yapılmadı. Çünkü daha önce birçok akademik araştırmalarda farklı ticari sperm hazırlama medyumları swim-up tekniği 


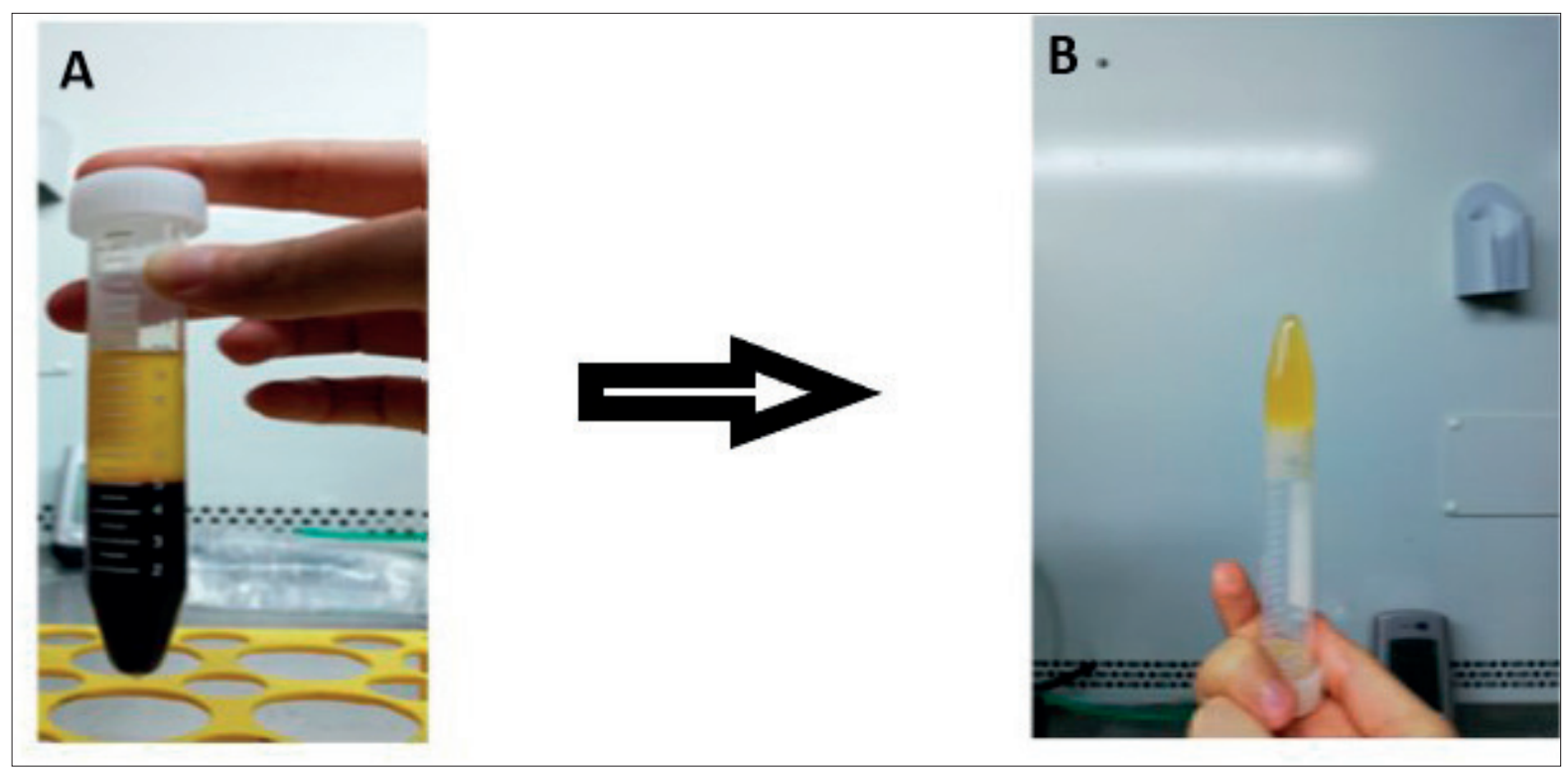

Resim 1. A) Santrifüj sonrası oluşan plazma, B) Aktivite TZP'nin jel formu

kullanılarak karşılaştırılmıştır. Çalışmamızda A-TZP ile swim-up yapılıp sperm motilitesine etkisine bakıldı. A-TZP için $900 \mu \mathrm{l}$ semen alınıp, örneklere 1:1 oranında PBS eklenip homojenize edildi. Daha sonra semen 1500 devirde 10 dk santrifüj edilip, süpernatant atılmış ve örneğin pelleti üzerine ortalama $400 \mu \mathrm{l}$ A-TZP eklenip homojenize edildi. Homojenize spermlerin üzerine ortalama $400 \mu \mathrm{l}$ A-TZP $45^{\circ}$ lik açı ile sızdırılıp katman oluşturacak şekilde bırakıldı. İşlem sonrası örnekler $37^{\circ} \mathrm{C}$ lik inkübatörde $45^{\circ}$ lik açı ile $45 \mathrm{dk}$ bırakıldı ve bu süre içerisinde spermlerin üstteki katmana yüzmesi beklendi. 15-30 ve 45. dk'da üstteki katmandan $10 \mu$ örnek alınarak makler sayım kamerasında sayı ve motilite analizleri yapılması planlanırken çalıştığımız her hastada A-TZP sadece üstte bir katman oluşturmayıp, homojenize edilmiş spermin altına inmiştir (swimdown). Bu nedenle "yüzen" spermlere ulaşmak için en altta veya üstte kalan A-TZP katmanından dikkatlice ve katmanı sarsmadan spermleri $10 \mu \mathrm{l}$ kadar analiz amaçlı alındı.

Tüm verilerin analizinde SAS University Edition 9,4 programı kullanıldı.

\section{Sperm Motilite Değerlendirme Skalası (WHO 2010)}

Sperm motilitesi analizinde hareketin dört farklı gruplandırması bulunmaktadır;

- +4 Motilite: Hızlı ve doğrusal hareket gösteren spermlerdir.

- +3 Motilite: Doğrusal bir hareket gösterip, +4 motilite hızında olmayan ya da +4 hızında olsa bile doğrusal hareket göstermeyen spermlerdir.
- +2 Motilite: Tek bir kare içinde hareketlilik gösteren veya bir kareyi aşamayan spermlerdir.

- +1 Motilite: İmmotil yani hareketsiz spermlerdir.

Dünya Sağlık Örgütü’nün 2010 verilerine göre sperm motilitesinin alt referans değeri $\% 40$ 'tır. İleri hareketlilik alt sınır değeri ise $\% 32$ olup, ileri hareketlilik $A+B$ yani +4 ve +3 motiliteye sahip spermlerin toplanmasiyla elde edilir. Toplam sperm motilitesi ise $A+B+C$ yani $+4,+3$ ve +2 motiliteye sahip spermlerin toplam değerini ifade etmektedir (WHO 2010).

\section{BULGULAR}

+4 motiliteye sahip spermler +3 'e benzer şekilde swim-up işleminin akabinde (yüzdürme başlangıcından itibaren 60 . Dakika) 15. dakikada en yüksek nokta da iken ilerleyen zamanlarda düştüğü gözlenmiştir.

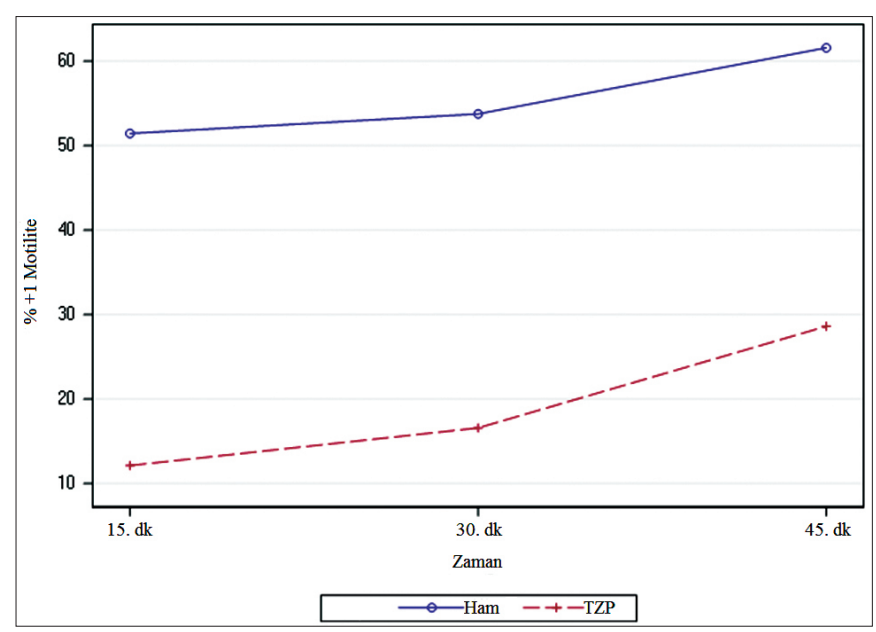

Grafik 1. Swim-up prosedüründe A-TZP ile muamele olmuş spermlerin zamana bağlı olarak +1 motilite değişimi. Grafiğe göre A-TZP ile muamele edilen kısımda +1 spermler (immotil) 15. dakikadan itibaren 45 . dakikaya kadar yaklaşık üç kat artmıştır. 


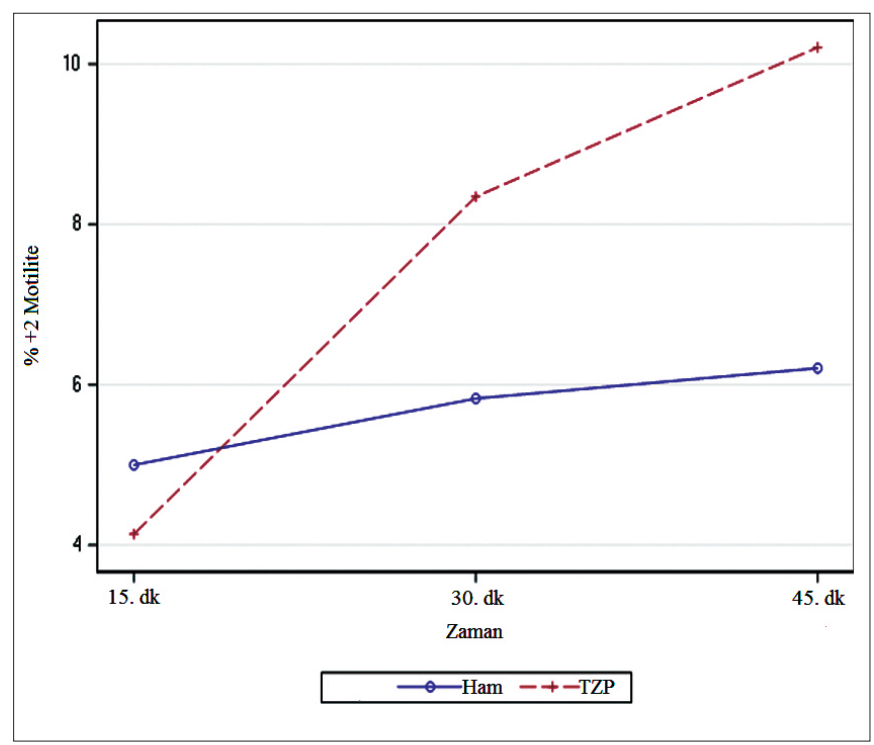

Grafik 2. Swim-up prosedüründe A-TZP ile muamele olmuş spermlerin zamana bağlı olarak +2 motilite değişimi. +2 motiliteye sahip spermlerin A-TZP ile inkübasyonu takiben swim-up sonrası (yüzdürme başlangıcından itibaren 90 . dakika) 45. dakikalarda yapılan değerlendirmelerde başlangıca göre yaklaşık 2,5 kat artth̆ı gözlenmiştir.

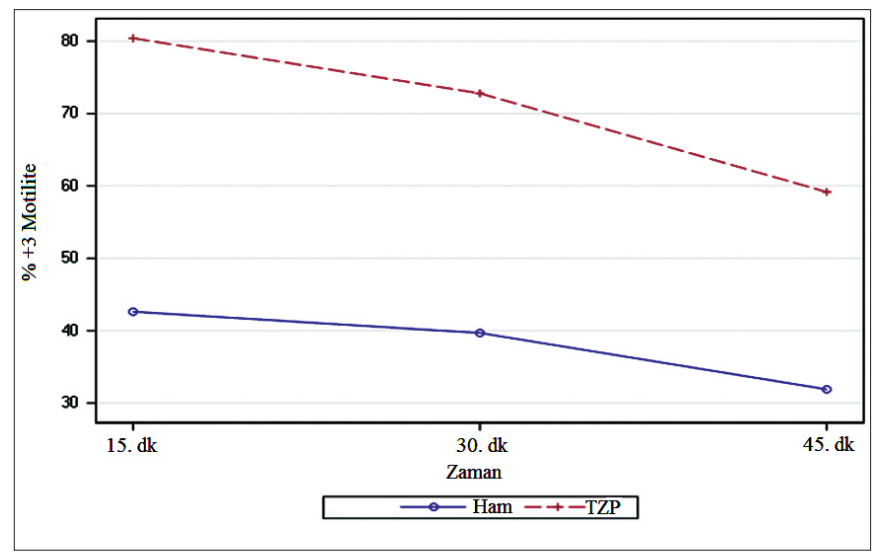

Grafik 3. Swim-up prosedüründe A-TZP ile muamele olmuş spermlerin zamana bağlı olarak +3 motilite değişimi. +3 motilite değerinin swim-up işleminin akabinde (yüzdürme başlangıcından itibaren 60. dakika) 15. dakikada yapılan değerlendirilmesinin en üst düzeyde olduğu tespit edilmiştir.

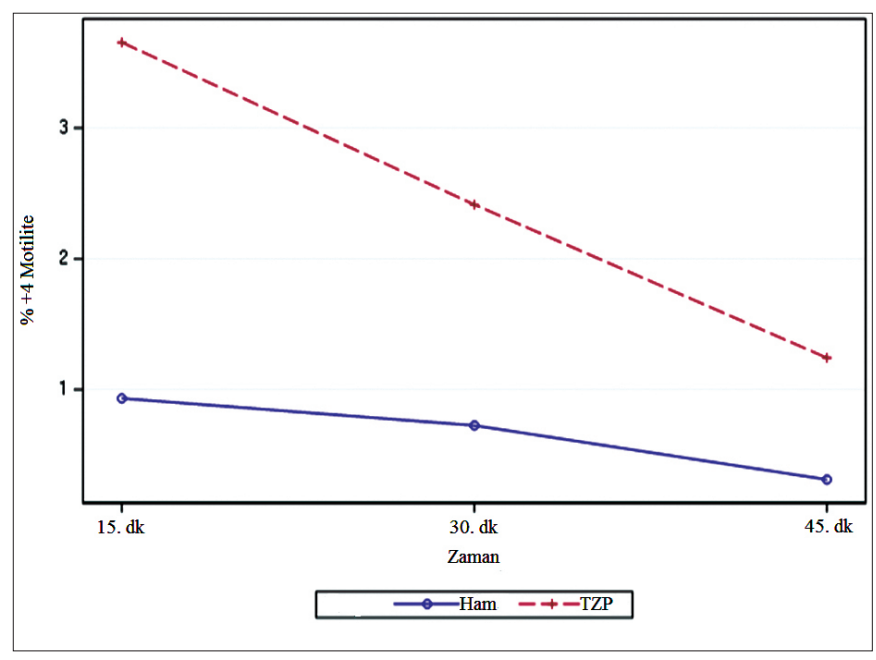

Grafik 4. Swim-up prosedüründe A-TZP ile muamele olmuş spermlerin zamana bağlı olarak +4 motilite değişimi

\section{TARTIȘMA}

Literatürde yer alan bilgilere göre swim-up metodu, kullanılan farklı sperm hazırlama teknikleri ile karşılaştırıldığında hazırlanması basit bir yöntemdir, reaktif oksijen türleri oluşumunu engellediği ve DNA bütünlüğü korunduğundan dolayı tercih edilen yöntem olmuştur. ${ }^{[11]}$ Çalışmamızda farklı bir medyum (yıkama sivisı) ile hazırlanan ve swim-up tekniği kullanılan kontrol grubu oluşturmadık. Yapılan çalışmalarda farklı markaların sperm hazırlama medyumları swim-up tekniği kullanılarak karşılaştırılmış olup sonuçlarının neredeyse standart hale gelmiş olmasından dolayı Aktive edilmiş Trombositten Zengin Plazma’nın etkinliğini araştırmaya odaklandık. ${ }^{[12]}$

A-TZP hazırlanmasında \%10'luk $\mathrm{CaCl}_{2}$ ile trombositleri aktifleştirme yöntemini tercih ettik. Literatürdeki verilere göre $\mathrm{CaCl}_{2}$ ile muamele edilen trombositlerden daha fazla büyüme faktörünü ortaya çıkardığını göstermiştir. Diğer bir yöntem ise trombositlerin soğuk-sıcak şokuna uğratarak büyüme faktörlerinin açığa çıkarılması şeklindedir. ${ }^{[13]}$

TZP ile ilgili farklı alanlarda tedavi edici araştırmalar yapıldığı görülmektedir. Bugüne kadar TZP'nin ortopedi, plastik ve rekonsrüktif cerrahi, diş hekimliği ve jinekoloji gibi farklı alanlarda kullanım bulduğunu bilmekteyiz. A-TZP'nin bu alanlarda kullanım bulması ise içerdiği büyüme faktörlerine dayanmaktadır. Bu büyüme faktörlerinin yara iyileşmesi, doku rejenerasyonu, progenitör hücrelerin tetiklenmesi gibi farklı fonksiyonları olduğu düşünülmektedir. ${ }^{[14]}$ Bizim bu çalışmadaki amacımız ise swim-up tekniğiyle hazırlanacak semen örneklerinde A-TZP'nin fonksiyonunun anlaşılması ve olumlu etkileri olduğu takdirde YÜT tedavilerine sunabileceği avantajları değerlendirmek olmuştur.

Bader ve ark. yaptığı çalışmada $\mathrm{H}_{2} \mathrm{O}_{2}$ kaynaklı oksidatif strese uğratılmış insan sperm hücrelerinde otolog TZP'nin in vitro etkisini incelemişlerdir. \%2'lik TZP tedavisi, strese uğrayan çalışma grubunda ROS-pozitif hücrelerde, DNA fragmantasyonunda, vakuolizasyonda ve ölü hücrelerde TZP olmayan gruba göre önemli düşüş göstermiş, yine TZP tedavisi uygulanan grupta özellikle progresif ve toplam motilitede ciddi artış meydana gelmiştir. ${ }^{[15]}$ Çalışmamızda elde ettiğimiz trombositleri aktive ederek ortaya çıkan Growth faktör kombinasyonu konsantre olarak kullanılmış olup; özellikle +3 ve +4 motil sperm değerlendirme sonucunda yüzdürme sonrası 15. Dakikada (toplam 60 dakika) motilitenin en yüksek seviyede olduğu tespit edilmiştir.

Yapılan bir çalışmada trombosit $\alpha$ granüllerinde bulunan VEGF'nin sperm motilite ve canlılığı üzerine etkisi 
araştırılmıştır. Çalışmada, insan spermi için 5, 10, 15 ve 20 ng/mL konsantrasyonlarda VEGF kullanılmış, maksimum etkinin $15 \mathrm{ng} / \mathrm{mL}$ 'de olduğu gözlemlenmiştir. VEGF'e maruz kalan spermlerde canlılık süresi uzarken sperm motilitesine olumlu sonuçları olmuştur. ${ }^{[16]}$

Spelekova ve ark.'nın bir çalışmasında sıçan ejekülatlarına trombosit de bulunan büyüme faktörlerinden EGF ilave edildikten 24, 48 ve 72 saat sonra motilite parametreleri kontrol edilmiştir. Çalışmada EGF'nin etkisinin ilk 30 dk'dan sonra ortaya çıktığı, sperm motilitesinde önemli bir etki gösterdiği ve 48 saatlik inkübasyon sonucunda ise en yüksek progresif motiliteye ulaşıldığı saptanmıştır. Sonuç olarak EGF'e maruziyet süresi ve EGF konsantrasyonu sperm motilite parametreleri üzerinde önemli etkilere sahiptir. ${ }^{[17]}$ Yaptığımız çalışmada ise inkübasyon süresinin uzaması ile birlikte A-TZP katmanında immotil (+1 motiliteye sahip) spermlerin sayısının arttığını gözlemledik (Grafik 1). Bunun nedeni kullandığımız A-TZP'nin konsantrasyonu ve tekniğiyle ilişkili olabilir. Yapılan ama yayınlanmamış verilere göre A-TZP ile basit yıkama yapılarak hazırlanan semen örneklerinde inkübasyon süresinin artışı motiliteyi olumlu yönde etkilemiştir.

Luo ve ark., VEGF’nin sığır oositlerinin matürasyonu üzerine etkisini araştırmış, VEGF ile muamele edilen oositlerin maturasyonunda VEGF'nin önemli etkisi olduğu sonucuna varılmıştır. ${ }^{[18]}$ Chang ve ark., yetersiz endometrium kalınlığı olan hastada, uterus boşluğuna TZP bırakılmıştır. Bu işlem 72 saat sonra tekrarlanmış ve yeterli endometrial kalınlaşma ve gebelik sonuçlarının iyileştirdiği gösterilmiştir. ${ }^{[19]}$

Yaptığımız çalışma, A-TZP'nin sperm motilitesine +3 ve +4 seviyesinde önemli oranda olumlu etkilediğini göstermiştir (Grafik 3-4). Biz bu olumlu etkinin özellikle Intra Uterin İnseminasyon (IUI) tedavisi gören hastalarda faydalı olabileceğini düşünüyoruz. Çünkü hem tekil büyüme faktörleri ile yapılmış çalışmalar, hem de konsantre A-TZP'yi kullanmış olduğumuz çalışmamız sperm üzerine olumlu etkiler göstermişken, Yajie ve arkadaşları da TZP'nin endometrial gelişme ve implantasyonu desteklediğini göstermişlerdir. ${ }^{[19]} \mathrm{Bu}$ bilgiler bize IUI hastalarında sperm motilitesinin artması ve endometriumun implantasyona hazırlanması bakımından A-TZP'nin oldukça efektif olabileceğini göstermektedir.

Yapılan çalışmanın sonuçları değerlendirildiğinde A-TZP ile inkübe edildikten sonra başlatılan swim-up uygulamasının ilk 15. dakikasında sperm motilite tablosu dikkat çekici olmuştur. A-TZP'nin sperm yıkama ve swim-up medyumu olarak kullanılan diğer ticari medyumlara alternatif olabileceğini düşünmekteyiz.
Hakem Değerlendirmesi

Dış bağımsız

Çıkar Çatışması

Yazarlar çıkar ilişkisi olmadığını beyan etmişlerdir.

Finansal Destek

Herhangi bir mali destek alınmamışırı.

Peer-review

Externally peer-reviewed.

Conflict of Interest

No conflict of interest was declared by the authors.

Financial Disclosure

No financial disclosure was received.

\section{KAYNAKLAR}

1. Delilbaşı L. In Vitro Fertilizasyon (IVF) Laboratuvar Yöntemleri (Yeni uygulamalar ve güncel yaklaşımlar). Ankara: Güneş Kitabevi; 2008.

2. Marx RE. Platelet-Rich Plasma (PRP): What Is PRP and What Is Not PRP? Implant Dent 2001;10:225-8. [CrossRef]

3. Dhillon RS, Schwarz EM, Maloney MD. Platelet-rich plasma therapy - future or trend? Arthritis Res Ther 2012;14:219. [CrossRef]

4. Alves R, Grimalt R. A Review of Platelet-Rich Plasma: History, Biology, Mechanism of Action, and Classification. Skin Appendage Disord 2018;4:18-24. [CrossRef]

5. Wu CC, Wu YN, Ho HO, Chen KC, Sheu MT, Chiang HS. The neuroprotective effect of platelet-rich plasma on erectile function in bilateral cavernous nerve injury rat model. J Sex Med 2012;9:2838-48. [CrossRef]

6. Tavukcu HH, Aytaç Ö, Atuğ F, Alev B, Çevik Ö, Bülbül N, Yarat A, Çetinel Ş, Şener G, Kulaksızoğlu H. Protective effect of plateletrich plasma on urethral injury model of male rats. Neurourol Urodyn 2018;37:1286-93. [CrossRef]

7. Nikolopoulos KI, Chrysanthopoulou E, Pergialiotis V, Korrou LM, Perrea DN, Dimitroulis D, Doumouchtsis SK. An animal experimental study on pubourethral ligament restoration with platelet rich plasma for the treatment of stress urinary incontinence. Cent Eur J Urol 2019;72:134-41. [CrossRef]

8. Culha MG, Erkan E, Cay T, Yücetaş U.. The effect of platelet-rich plasma on Peyronie's disease in rat model. Urol Int 2019;102:21823. [CrossRef]

9. Shirvan MK, Alamdari DH, Ghoreifi A. A novel method for iatrogenic vesicovaginal fistula treatment: autologous platelet rich plasma injection and platelet rich fibrin glue interposition. J Urol 2013;189:2125-9. [CrossRef]

10. Mirzaei M, Daneshpajooh A, Farsinezhad A, Jafarian Z, Ebadzadeh MR, Saberi N, Teimorian M. The therapeutic effect of intravesical instillation of platelet rich plasma on recurrent bacterial cystitis in women: a randomized clinical trial. Urol J 2019;16:609-13. [CrossRef]

11. Anbari F, Halvaei I, Nabi A, Ghazali S, Khalili MA, Johansson L. The quality of sperm preparation medium affects the motility, viability, and DNA integrity of human spermatozoa. J Hum Reprod Sci 2016;9:254-8. [CrossRef]

12. Kim EK, Kim EH, Kim EA, Lee KA, Shin JE, Kwon H. Comparison of the effect of different media on the clinical outcomes of the density-gradient centrifugation/swim-up and swim-up methods. Clin Exp Reprod Med 2015;42:22-9. [CrossRef]

13. Roffi A, Filardo G, Assirelli E, Cavallo C, Cenacchi A, Facchini A, et al. Does platelet-rich plasma freeze-thawing influence growth factor release and their effects on chondrocytes and synoviocytes? Biomed Res Int 2014;2014:692913. [CrossRef] 
14. Turan Y, Erbil DAH, Koç DE. Plateletten Zengin Plazma ve Dermatoloji. Dermatoz 2011;2:355-60. https://docplayer.biz. tr/2592037-Plateletten-zengin-plazma-ve-dermatoloji.html

15. Bader R, Ibrahim JN, Moussa M, Mourad A, Azoury J, Azoury $\mathrm{J}$, Alaaeddine N. In vitro effect of autologous platelet-rich plasma on $\mathrm{H} 2 \mathrm{O} 2$-induced oxidative stress in human spermatozoa. Andrology 2019;8:191-200. [CrossRef]

16. Iyibozkurt AC, Balcik P, Bulgurcuoglu S, Kardaş Arslan B, Attar R, Attar E. Effect of vascular endothelial growth factor on sperm motility and survival. Reprod Biomed Online 2009;19:784-8. [CrossRef]
17. Spalekova E, Makarevich AV, Lukac N. Ram Sperm Motility Parameters under The Influence of Epidermal Growth Factor. Vet Med Int 2011;2011:642931. [CrossRef]

18. Luo H, Kimura K, Aoki M, Hirako M. Effect of vascular endothelial growth factor on maturation, fertilization and developmental competence of bovine oocytes. J Vet Med Sci 2002;64:803-6. [CrossRef]

19. Chang Y, Li J, Chen Y, Wei L, Yang X, Shi Y, Liang X. Autologous platelet-rich plasma promotes endometrial growth and improves pregnancy outcome during in vitro fertilization. Int J Clin Exp Med 2015;8:1286-90. https://www.ncbi.nlm.nih.gov/pmc/ articles/PMC4358582/ 